\title{
Public Policies, Tourism and Inovation: an analysis of the cases turismo 4.0 [Portugal] and smart tourism destination [Spain]
}

\author{
Alexandre Augusto Biz, Dores Cristina Grechi*
}

\section{Keywords:}

Innovation,

Public Policies,

Tourism,

Institutionalism

Article History:

Submitted: 07.05.2021

Accepted: 15.12.2021

\begin{abstract}
The paper on public policies, tourism and innovation gave the opportunity to reflect on traditional concepts of public policies, based on the current scenario permeated by changes caused by innovations in different areas. The effort to relate the different theoretical approaches was based on the analysis of two exemplary cases: Portugal and Spain. Both countries have produced innovative public policies regarding tourism management, be they procedural, organizational, marketing, institutional or reverse innovations. The methodology had a qualitative approach, comprising theoretical review and case study. The analysis of the documents was based on the reference on public policy analysis, with attention to the models of institutional and systemic orientation and the cycle of public policies on the possibilities of innovation for tourism, and the vision of democratic innovation. Knowing the historical process and the institutional context inherent to the cases studied allowed a critical look at the Brazilian panorama, considering the challenges and possibilities of the policies for the sector, based on innovation and all stages of the policy cycle.
\end{abstract}

\section{Introduction}

Technological advances and the speed with which information is disseminated have caused profound impacts on the way tourism services are transacted, i.e., the way products related to the travel sector are produced, disseminated and delivered (MTur, 2020).

For Muniz et al. (2021) technologies also impact the way in which the knowledge of consumers from their tourist experiences can be managed by destination managers (Destination Management Organization) to generate value and competitive differences in services and tourism products. It is noticed that technological advancement produces effects on the vision of tourism public policy as economic aspects, participatory (civil society), social development and digital inclusion.

For institutional economics, the relations between the actors of a system occur based on three models of governance: market, hierarchy (firm) and mixed (Williamson, 1996; Gomes; Santos, 2008). The mixed models bring together actors from the public, private and third sector spheres. As far as the public management of tourism in Brazil is concerned, it can be observed that since the nineties of the last century there has been the implementation of guidelines aimed at fostering mixed governance structures, first at the municipal level (MTur, 1998) and then at the regional level (MTur, 2004).

The purpose of creating mixed organizations for decentralized tourism management was to encourage the democratic participation of key stakeholders in tourism (MTur, 2006). International organizations, including the World Tourism Organization (UNWTO) and the Organization for Economic Cooperation and Development (OECD) disclosed in their guiding documents for sustainable tourism development, the importance of encouraging dialogue and participation in the development, monitoring and evaluation of tourism public policies (Wold Travel and Tourism Council - WTTC, 2017).

In parallel, the technological revolution has caused incremental innovations (constant improvements) and disruptive innovations (paradigm shattering) also in the way of exercising this popular participation. The main trends in public tourism management point to the need for more

\begin{aligned} \hline *Corresponding Author & \\ \hline Alexandre Augusto Biz: & $\begin{array}{l}\text { Assoc. Prof., Santa Catarina Federal University, Florianópolis, Brazil, Email: alexandre.biz@ ufsc.br, } \\ \text { Orcid Id: O000-0003-3235-9328 (iD }\end{array} \\$\hline Dores Cristina Grechi: $: & \begin{array}{l}\text { Estat. Nivel V, Mato Grosso do Sul State University, Dourados, Brazil, Email: doresgrechi@ gmail.com, } \\ \text { Orcid Id: 0000-0002-4481-0166 iD }\end{array}\end{aligned}$


customization in the configuration of models adapted to the reality of each place, people and historical context (Ivars-Baidal et al., 2017).

Since the historical trajectory influences the development (North, 1990) and that each place has its way of cooperating and collaborating, varied approaches need to be used to analyze the relationship between individuals and institutions, instead of single methods (Conceição, 2002), as well as, different communication channels such as, for example, internet, chats, mobile phones, applications and social networks, can reach the largest possible number of citizens, demands and problems (Sontag et al., 2020).

In a scenario of constant resilience, it is justified to reflect on the interfaces between innovation and public policies, since several innovations have forced some issues to enter the political agendas either incrementally, or as a disruptive factor (Souza, 2006). The opposite also requires reflection, since innovation needs specific public policies.

Public policies are conceptualized in many different ways, among these, there are theorists who position the policy as a formal institution, which is influenced by informal institutions, such as habits and local culture (North, 1990). That is, it will be the rule that will guide the direction of action of individuals, organizations and the very development that is desired for a destination, however, individuals and the context can also influence the policies. Moreover, policies have the function of deciding which problems will be solved at a given time and in a given context (Gelinski; Seibel, 2008). Or which will not be (Dye, 2005).

For Frey (2000), the construction of a public policy comprises a development cycle in different stages, such as: the identification of problems, the choice of problems that should enter the political agenda, policy formulation, decision-making, implementation, monitoring and evaluation.

The choice of which problem should be incorporated into the political agenda will depend on some factors, one of which is the pressure from the actors and other institutions (Souza, 2006). A second factor that impacts decision-making is the bounded rationality that permeates the entire process of building a policy, since it is not always possible to make the best decision due to not having all the necessary information (Somon, 1955).

But what would be the relationships between public policies and tourism? Tourism is one of the most cross-cutting economic sectors, so there are different types of actors and institutions directly and indirectly related, and it is a data and information intensive activity, which requires policy directions with strategic and integrated vision between different economic sectors.

Baptista, Pocinho and Nechita (2021) mention that tourism public policies should show a concern for the development of the sector and, at the same time, improve the quality of life of the population.

The Organization for Economic Cooperation and Development - OECD, presented in 2010 a study called OECD Tourism Trends and Policies 2010, in which the tourism sector faced important challenges that impact on the developed in the long term quoting the strategic role of tourism public policy for: a) changes in global markets, b) impact of tourism on the economy, c) climate and sustainable change, d) knowledge economy, e) human resources and f) competitiveness and productivity.

Another strategic component for tourism public policies is in innovation. According to Cooper et al. (2019) innovation is essential for the competitive future and economic survival of a tourism destination, justifying that innovation involves knowledge, new products and services, and new thinking about tourism.

Brandão (2014) describes that innovation in the tourism sector is based on seven possibilities, namely: a) in service and product innovation; b) innovation in processes; c) organizational innovation; d) innovation in marketing; e) institutional innovation; f) reverse community innovation (innovations that benefit local residents); and g) reverse innovation to business (innovations that bring benefits to other companies). Note the reflection Brandão (2014) made when presenting the vision of reverse innovation, that is, what benefits the innovation will bring both to the community and to businesses.

Zach and Hill (2017) summarize why innovation is a critical factor for a tourist destination, first by competition with other tourist destinations for consolidation with tourists, and second, innovation favors the understanding of socioeconomic determinants that are in constant change. In other words, innovation can be understood as a fundamental process to face the stagnation of a tourist destination (Butler, 1980), from its management (Destination Management Organization), to the providers of services and tourism products (companies that operate directly and indirectly in tourism) to the local community. 
It should be noted that tourism comprises mostly micro and small businesses under family management, which are deprived of access to the different aspects of innovation due to non-inclusive public policies. On the other hand, there is the local community, which should also benefit directly and indirectly from innovations.

Therefore, the question is: how can stage 1 (identifying problems and deciding what will be on the agenda), as well as part of stage 2 (formulating alternatives) of the cycle of public policy for tourism impact on the innovation process (considering its different aspects), in a way that contemplates the entire tourism production chain, especially micro and small enterprises? The research questioning falls on the agenda, in an initial way, because the insertion of a problem in the political agenda is the beginning of the process of developing a policy. For Sontag et al. (2020, p.106): "The study of the public policy agenda is the basis for investigations focused on the following stages of the cycle: formulation, implementation and evaluation".

Based on the premise that public policies are important for innovation to occur and vice versa, this article aims to analyze the interfaces between public policies for tourism and innovation analyzing two contemporary cases and global references, the proposal of Portugal with Tourism 4.0 and the proposal of Spain with Smart Tourism Destinations (STD) that followed different constructions, but that have in their strands the reflections presented by Brandão (2014).

\section{Tourism public policies under the systemic and institucional approach}

The complexity of the tourism phenomenon intensifies to the extent that the current society, postmodern (Hall, 2014) or liquid (Bauman, 2007) also becomes more complex. As tourism is a social phenomenon, the operationalization of the activity will reflect the behavior and demands of the current society.

Modern tourism, i.e., the displacement of people to places far from their usual environment, for various reasons and for a fixed time, arises with the industrial revolution in the nineteenth century. It became possible thanks to the modernization of means of transport, changes in labor relations, entry of women into the labor market, technological innovations in the area of communication and excessive pollution and urbanization that encouraged people to seek places in the countryside for rides and enjoyment of free time (Dias, 2005).
The digital revolution, which began between 1950 and 1970, was characterized by the use of computers and, later, by the internet, impacting the way people study, shop, relate to each other and, also, how they spend their free time. In the last thirty years, the emergence and popularization of social networks have stimulated innovations of all kinds, drastically changing the transactions between the elements that make up the tourism system.

The tourism phenomenon can be analyzed under different approaches, from hermeneutics, phenomenology, positivism, dialectics and also under a systemic approach (Panosso Netto; Castillo Nechar, 2014). The systemic approach, in Brazil, has in Beni's theory (1998), its greatest exponent, in which the author presents a representative scheme of the tourism system, the elements that configure it and the relationships between them.

Internationally, the systemic approach in the study of tourism was originally discussed by Cuervo (1967), Leiper (1979), Boullón (1997), Getz (1996) and Pearce (1995). Other works have advanced from Beni's original scheme, in an attempt to try to incorporate into the model the complex character of a network society, in which transactions between elements are much more intense, fluid and fast (Baggio et al.; 2010; Velasquez; Oliveira, 2016; Beni \& Moesch, 2017; Vilela; Costa, 2018).

For the model of Beni (1998), the tourism system has different groups of relations that can be analyzed individually or as a whole. Among them, the set of operational actions, that is, the tourism production chain (Costa; Souto Maior, 2006); the set of ecosystemic relations (ecological, economic, cultural and social environment) and, finally, the set of structural organization, composed by the infrastructure and superstructure.

In this research, although the interest falls specifically on the superstructure element, it is imperative to consider the effect of other elements on the superstructure, taking into account the complexity of the phenomenon and its systemic character.

According to Beni (1998) the superstructure is composed of policies, plans, administrative structures, and information and statistical systems related to tourism. All, in a way, interconnected. Under the institutionalist view, or more specifically the New Institutional Economics (NIE), policies are considered formal institutions, subject to bounded rationality, uncertainty and opportunism (Williamson, 1985). That is, the 
superstructure would be what North (1990) calls environment and institutional arrangement. In other words, the environment would be the rules of the game and the arrangement are the governance structures where the game is played.

For Chang and Evans (2005, p. 02), institutions are "mechanisms that enable the achievement of purposes that require supra-individual coordination and, even more importantly, that are constitutive of the interests and worldviews of economic actors".

Once public policy is understood as a formal institution subject to the interferences of all the other elements of the system, it is understood that the opposite is also true, that is, policy is also capable of interfering in the other elements. Hodgson (2000) argues that this process is cyclical (circular causation) happens as time passes (Figure 1). Institutions shape and are shaped by individual action (Chang; Evans, 2005).

Figure 1. Superstructure in the light of institutionalist theory Article subtitle (second level title)

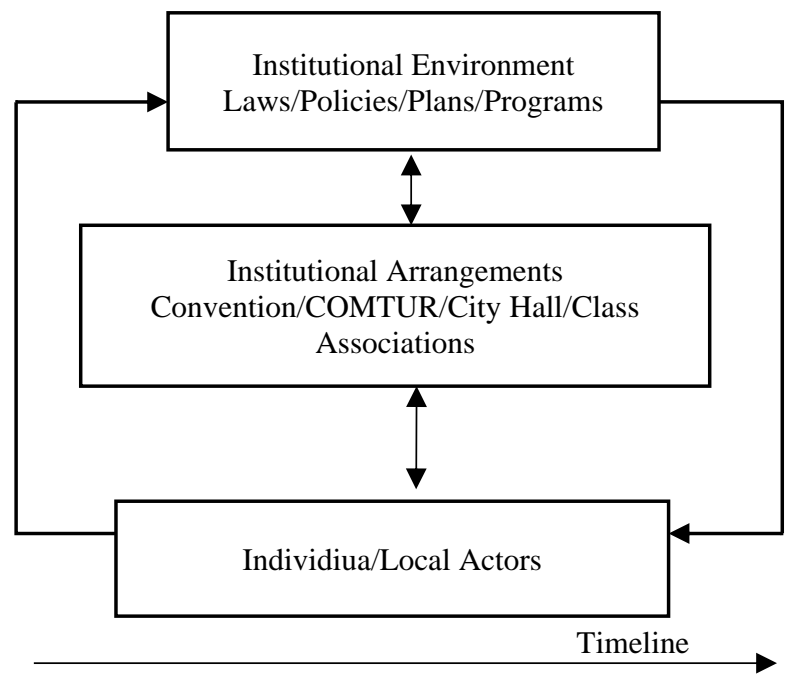

Source: own preparation, adapted from Hodgson (2004).

Therefore, for institutional economics, the rules and organizations are dependent on the past (Conceição, 2002), which makes even the innovations are much more of incremental order, especially in the field of public policies (Souza, 2007). Thus, "each place will need to develop strategies that allow to efficiently arbitrate situations of disagreement" (Grechi et al., 2019, p. 232).

Several theoretical models can be used in the analysis of public policies, such as incrementalism, game theory, rationalism, theory of elites, interest groups, institutionalism, systems theory and others more (Tude, 2010). These models are not exclusive in their entirety, some of them, at some point may be complementary in the process of building policies, or even in their analysis.

To analyze tourism public policies and the relationship with innovation it was chosen the institutionalist and cycle approaches for understanding that they can be useful and complementary: "In the context of public policies, the institutionalist schools show potential and are being used in various analyses, contemplating different moments of public policy" (Chechi \& Grisa, 2019, p. 736).

The institutionalist strand has its origin in the studies of Veblen (1919) in the early twentieth century, for which institutions are a reflection of the habits of individuals. Veblen (1919) is inspired by Darwin's studies, so his institutionalist theory is also evolutionary. For Veblen (1919) innovations are not given, for example, but the result of a whole process of construction of individuals and impacted by endogenous characteristics.

Briefly, the institutionalist schools are divided between the old institutionalists (OIE), whose exponents are Veblen (1919), Commons (1931) and Mitchell (1914), the neoinstitutionalists (NEO), such as Meyer (1977) and Ostron (2007), including the subcurrents of sociological and historical neoinstitutionalism, and the new institutional economics (NIE), represented by Coase (1937), Williamson (1985) and North (1990). Among the contemporary institutionalists are Chang (2002) and Hodgson (2006).

The emergence of these different currents was intended to be a counterpoint to the neoclassical view of economics, for which man is a totally rational being, with given preferences, in a context of equilibrium and always seeking utility maximization.

It is noteworthy that the different currents were complementing and contrasting over time, but in order to better explain the different realities that presented themselves.

According to Cavalcante (2014, p. 389), "contemporary institutionalists move more fluidly within these three ways of understanding and defining institutions, which reflects the attempt, at least in Hodgson's case, to reconcile the OIE and the NIS". 
Table 1: A summary of the different institutionalist approaches in the context of public policy

\begin{tabular}{|c|c|c|}
\hline $\begin{array}{c}\text { Institutionalist } \\
\text { Approaches }\end{array}$ & Features & Conclusions concerning public policies \\
\hline $\begin{array}{l}\text { Old Institutional } \\
\text { Economy (OIE) }\end{array}$ & $\begin{array}{l}\text { It considers individuals and the influence of } \\
\text { the environment in the construction of } \\
\text { politics and, also, the transformations over } \\
\text { time. The individuals, their habits and } \\
\text { routines (Veblen, 1919); the expansion of } \\
\text { individual preferences in collective action } \\
\text { (Commons, 1931) }\end{array}$ & \multirow{2}{*}{$\begin{array}{l}\text { This approach makes it possible to analyze the legitimacy of } \\
\text { public policies, programs and projects and the capacity of } \\
\text { arrangements to favor or not the implementation of a public } \\
\text { policy. } \\
\text { The approach of the old institutional economics and sociological } \\
\text { neo-institutionalism in the cycle of public policy, would } \\
\text { contribute to the analysis of all stages. It can be inferred that } \\
\text { social conventions, habits, routines would influence the } \\
\text { prioritization of themes and choice of instruments, their } \\
\text { implementation and evaluation. }\end{array}$} \\
\hline $\begin{array}{l}\text { Sociological neo- } \\
\text { institutionalism }\end{array}$ & $\begin{array}{l}\text { Public policy, in this context, would be an } \\
\text { action influenced by the environment and the } \\
\text { conventions that legitimize the process } \\
\text { before individuals and organizations in that } \\
\text { context. }\end{array}$ & \\
\hline $\begin{array}{l}\text { Historical neo- } \\
\text { institutionalism }\end{array}$ & $\begin{array}{l}\text { The evolution of public action is associated } \\
\text { with the adaptive processes of society, state } \\
\text { and interest groups and the asymmetry of } \\
\text { power through time. }\end{array}$ & $\begin{array}{l}\text { In this strand, public policy analysis focuses on power relations } \\
\text { and the influence of the historical process on both agenda } \\
\text { formation and policy implementation. } \\
\text { Policy analysis, as with OIE, takes into account path dependency, } \\
\text { including that of groups trying to stay in power. }\end{array}$ \\
\hline $\begin{array}{l}\text { New Institutional } \\
\text { Economics (NIS) } \\
\text { and Rational } \\
\text { Choice Neo- } \\
\text { institutionalism }\end{array}$ & $\begin{array}{l}\text { Public policy is understood as a tool, whose } \\
\text { purpose is to regulate and solve, seeking } \\
\text { efficiency. } \\
\text { In these two currents it is assumed that policy } \\
\text { makers are maximizers and rational and that } \\
\text { institutions are rules agreed upon to solve } \\
\text { dilemmas of collective action, i.e., reduce } \\
\text { transaction costs. }\end{array}$ & $\begin{array}{l}\text { The approach considers policy making as an objective process, in } \\
\text { which it is possible to perceive the best decision to be made, and } \\
\text { that this will be absorbed by individuals. }\end{array}$ \\
\hline $\begin{array}{l}\text { Contemporary } \\
\text { Institutionalists }\end{array}$ & $\begin{array}{l}\text { They move between different ways of } \\
\text { understanding and defining institutions in an } \\
\text { attempt to reconcile OIE and NIS. } \\
\text { Change and resistance to change - path } \\
\text { dependence (Hodgson, 1992). }\end{array}$ & $\begin{array}{l}\text { Policies would be the rules of the game (NIS) but also the result } \\
\text { of mental models (OIE). That is, Individuals and institutions } \\
\text { would be in an uninterrupted co-evolutionary process. One } \\
\text { molding the other in a "circular causation", since institutions } \\
\text { restrict, but also allow human interaction. }\end{array}$ \\
\hline
\end{tabular}

Despite being considered neoclassical, the NIS institutionalists do not ignore that the process of building a policy, or the transactions between individuals, are permeated by bounded rationality and opportunism, in addition, other ingredients need to be incorporated, such as: frequency of transactions, asset specificity (time, investment, brand, location, dedicated assets, physical and human) and uncertainty (Williamson, 1996).

Therefore, analyzing a policy from an institutionalist and systemic perspective means identifying the actors involved in the process, the existing organizations or governance structures, the rules in force at the time and the relationships between actors. In addition, it is essential to incorporate the discussion of how the context (historical, economic, ecological, social, cultural and technological) impacts the process of building the political agenda.

The institutionalist approach to public policy advocates that changes in the design of institutions should be cautious, because they will not always result in a positive evolution (Conceição, 2002). To be efficient, one must consider that the institutional design should also be accompanied by changes in the political, cultural, social and, why not, technological context. Hodgson (1992) contributes when he states that more than understanding how institutions are established, one should understand the process by which they are modified.

The use of the institutionalist framework to analyze public tourism policies is still timid, but can be found in the works of Gomes and Santos (2007), who dealt with the influences of public tourism policies on transactions between agents; Gomes (2008), who used the transaction costs approach to analyze the relationships between the actors of an instance of tourism governance in Minas Gerais; Alban (2021), who used the NIS to analyze the case of tourism in Praia do Forte (BA); Grechi (2011), to analyze the institutional matrix of tourism in Bonito (MS); Arruda , Mariani and Caleman (2014), on coordination and governance structures in a tourism production system; Falaster, Zanin and Guerrazzi (2017) demonstrated the potential of using institutionalist theory in tourism studies; Gomes (2018) on tourism public policies and entrepreneurs, in which he discusses public policies, tourism and institutionalism and Gomes, Giannini and Bassani (2020), who make an 
institutionalist analysis of entrepreneurs and public sector in the municipality of Morretes.

The aforementioned works corroborate the suggestion of Chechi and Grisa (2019), for whom it is important to consider in the phases of the policy cycle the various aspects of institutionalist approaches, among them culture, values, power and interest, which make the process of building agendas and the policies themselves complex. Therefore, understanding how the relationship between innovation and tourism public policy occurs is essential to understand the processes of positive change for the development of tourist destinations.

\section{The process of building a public policy and the policy cycle model}

Discussing public policies is related to understanding the role of the state, which has been changing as society has also changed. Studies in this field show that the State, in past centuries, was responsible for issues related to the maintenance of private property, security and attention to borders. Currently, the state also assumes the role of maintainer of social welfare (Tude, 2010).

Also related to social welfare, the United Nations UN has established seventeen sustainable goals (SDGs) by 2030, being the seventeenth of which states the importance of partnerships and the means to implement them. This goal is consistent with public policies in the sense that policies are means to achieve purposes established in the collective, often through partnerships.

In any public policy, be it tourism or not, the collective and citizen participation is essential for the established guideline to meet the needs of the policy target audience. However, in tourism, the target audience, in most cases, is the tourist, who does not resides in the city (Sontag et al., 2020).

In these terms, it is essential to think the public policy of tourism in its various perspectives. According to Frey (2000), policy can be understood from three dimensions: as a formal institution (laws and rules), as the process or path to decisionmaking and, finally, as a result, in the form of a specific policy.

In addition, Tude (2010) includes three more aspects in the study of policies: the political network (actors and institutions responsible for holding discussions about problems to be transformed into agenda), the political arena (movement to balance conflicts and consensus among actors, resulting in different types of policy) and also the cycle of public policies (Lassasswell, 1956; Sabatier, 2007; Kingdon, 2011).

For Rua (1998), politics would be the way to settle the conflicts that arise from the different needs and opinions present in society, it would be the counterpoint to the use of coercion. And they are the decisions and actions on where and when resources will be allocated. The author distinguishes between public policy and political decision, being the decision the equivalent of the choice that the actors make about the available alternatives before having a policy.

According to Gelinski and Seibel (2008) and Araújo and Rodrigues (2017), the distinct theoretical frameworks are complementary and may intersect at various moments, despite being different currents of thought. The authors present four models that they consider promising in the field of public policy analysis: the political cycle model, the multiple flows model, the interrupted equilibrium model and the theoretical framework of cause or interest coalitions. In this study, the cycle model will be used to present how the policy is processed in different stages and, complementarily, the systemic, institutional and interrupted equilibrium models, specifically when thinking about innovations that cause major disruptions in specific contexts (Janes et al., 2007).

The cycle (or sequential) model consists in understanding how the construction of a public policy occurs, its advantage is to facilitate the understanding of a complex process from the moment that separates the process into distinct but concatenated parts. According to Araújo and Rodrigues (2017), the original model was developed in the late 1950s by Lasswell, inspired by Easton's systemic approach.

Despite having received criticism, like the other models, it also received contributions and was consolidated with the stages of problem identification, agenda formation, development of alternatives, implementation, monitoring, evaluation and change.

The processing of demands from organized society (workers, government, private initiative, international agencies and media) occurs through the political system, which needs to meet the different needs that arise, whether new, recurrent or repressed (Easton, 1968).

For a state of affairs to become a problem with the scope of a political problem, there are three 
situations: collective or individual political mobilization with power resources; a situation of crisis or calamity and, finally, a situation of opportunity, where the actors see advantages in facing that problem. Such situations are related to the interrupted equilibrium model. Baumgartner and Jones (1999), authors of the interrupted equilibrium model, also emphasize the power of the media or the impact of some current policy issue (Gelinski; Seibel, 2008). From then on, the problem becomes part of the political agenda and the next stage will be the development of alternatives by the players involved, being the moment when the neuralgic issues concerning the problem come to light, each player will seek, by means of power struggle, to impose their point of view and it will be up to the public manager to conduct the situation (Rua, 1998).

Alternatives may be designed from incremental and conservative perspectives (usually when agendas have high conflict potential), or more rational ones, where cost-benefit aspects are strongly considered. A third route mixes incremental and rational perspectives, leaving structural agendas in the incremental mode and the other agendas in the rational mode. In short, the alternative chosen to solve the problem at hand will be the one that minimizes losses for the actors that have the power of decision at that specific moment (Etzioni, 1967).

Regarding the agenda-setting stage, Souza (2006) concludes that the construction of a collective consciousness about a certain problem is a fundamental aspect for a problem to become a policy. Mainly because it is a bottom-up process. For the author, there are also the actors she calls "visible" (politicians, media, parties, pressure groups) and the invisible ones (academics and bureaucrats), the former defining the agenda and the latter the alternatives.

This is where the intersection with innovation occurs, since technological changes have promoted new collectives, even informal ones, which announce changes in the political game. Anyway, the authors agree on one aspect, all models of analysis, construction and formulation of public policies can complement each other, to blend, so that policies get closer to the real needs of the largest number of people and in the most innovative possible way.

\section{Public Policies and Innovation in Tourism}

There are different versions of the concept of innovation. The precursor of the concept and typology was Schumpeter (1934) with his work "The theory of economic development" being this the basis of all theories. The OECD/EUROSTAST (2018) describe innovation as a new or improved product or process that differs significantly from previous products (units or processes) and that was made available to users or put into use by the unit.

Table 2 shows the main types of innovation cited by OECD/EUROSTAST (1997) that can be applied to tourism, namely:

Table 2. Main types of innovation

\begin{tabular}{|l|l|}
\hline \multicolumn{1}{|c|}{$\begin{array}{c}\text { TYPE OF } \\
\text { INNOVATION }\end{array}$} & \multicolumn{1}{c|}{ EXPLANATION } \\
\hline Product innovation & $\begin{array}{l}\text { Is the introduction of a new or } \\
\text { significantly improved good or service } \\
\text { with respect to its characteristics or } \\
\text { intended uses. It includes significant } \\
\text { improvements in technical specifications, } \\
\text { components and materials, embedded } \\
\text { software, ease of use or other functional } \\
\text { characteristics. }\end{array}$ \\
\hline Process innovation & $\begin{array}{l}\text { Is the implementation of a new or } \\
\text { significantly improved production or } \\
\text { distribution method. It includes significant } \\
\text { changes in techniques, equipment and/or } \\
\text { software. }\end{array}$ \\
\hline $\begin{array}{l}\text { Marketing } \\
\text { innovation }\end{array}$ & $\begin{array}{l}\text { Is the implementation of a new marketing } \\
\text { method with significant changes in } \\
\text { product design or packaging, product } \\
\text { positioning, promotion or pricing }\end{array}$ \\
\hline $\begin{array}{l}\text { Organizacional } \\
\text { innovation }\end{array}$ & $\begin{array}{l}\text { Is the implementation of a new } \\
\text { organizational method in the company's } \\
\text { business practices, workplace organization } \\
\text { or external relations. }\end{array}$ \\
\hline
\end{tabular}

Hjalager (2010) analyzed the research on tourism innovation from the typologies quoted in Table 2. In the end, he highlighted ten gaps to be explored: i. Innovation processes; ii. Driving forces (external factors); iii. Barriers to innovation in tourism; iv. Economic and innovative performance; v. Technological innovation; vi. Diffusion of innovation; vii. The role of entrepreneurship; viii. Policy study and evolution; ix. Innovation and Academia; and $\mathrm{x}$. Theories of innovation development in tourism.

Weindenfeld (2013) analyzes that tourism innovations, by their characteristics, are rarely major industry-wide breakthroughs, but more often constitute minor changes or improvements.

Kofler, Marcher, Volgger and Pechlaner (2018) cite three other factors that impact the process of innovation in tourism, these being: massification of a tourist destination (regular attendance), the characteristic of tourism sector companies 
consisting of small and medium-sized enterprises that do little innovate and/or transfer sectoral knowledge and the relationship with the public sector.

Domareski-Ruiz, Gândara and Chim-Miki (2015) who brought the vision of tourism territorial innovation as a strategy to consolidate a tourist destination structured by four pillars denominated as territorial competitiveness: talent; innovation; connectivity; and entrepreneurship adapted from the State of European Cities Report, published in the year 2007 (Domareski-Ruiz et al., 2017).

However, for any discussion that relates public policy, innovation and its area of application as, for example, tourism, it is necessary to discuss another typology that anticipates those cited by DomareskiRuiz et al. (2017), which is the democratic innovation described by Smith (2009) 1 .

Democratic innovation is about moving citizens beyond traditional modes of institutionalized engagement by asking how unequal participation can be overcome with innovations, how citizens can be empowered in the decision-making process, how the environment can be structured to enable informed judgements and how the process can be open and transparent (Smith, 2009).

Dryzek (2009) emphasizes that democracy is divided into three parts: the private space where political conversations and interactions occur in everyday contexts; the public space over contexts that have been created to discuss political concerns; and the empowered space where binding collective decisions are made (the democratic innovation).

Finally, Gherghina, Ekman, and Podolian (2019) describe that democratic innovations can be understood as institutions that are specifically designed to increase and deepen citizen participation in policy decision-making.

These processes should be established in public policies. For Ratten and Braga (2019), the public sector vision for tourism innovation policies should be focused on the creation of an innovative tourism ecosystem including a collaboration between stakeholders (private and public sector) and the community (citizen).

The implementation of a public policy follows three categories, top down when defined by the public sector, bottom up when demanded by the tourism sector, and interactive or hybrid when discussed with stakeholders and the community (citizen)
(Birkland, 2005; Hall, 2014; Rodrigues, Williamans, \& Hall, 2014).

This interactive/hybrid discussion occurred in Spain in the construction, in 2007, of the Spanish Tourism Plan Horizonte 2020, being the pioneer country in consolidating an agenda of innovation policies in tourism with the purpose of overcoming the perceived barriers to innovation in the sector with the predominance of small and micro enterprises - SMEs, low level of investment in research and innovation, lack of creativity and entrepreneurship and retention of human capital, through three specific programs, innovation, knowledge and talent attraction (Rodrigiues et al., 2014).

In this line, the Government of Portugal approved by the Resolution of the Council of Ministers 134, of 27 September 2017, an innovation policy agenda in tourism called "Tourism Strategy 2027" with the purpose of boosting the economy, affirming Portugal as an international reference hub in innovation and entrepreneurship (Portugal, Presidency of the Council of Ministers, 2017).

\section{Methodology}

The methodology had a qualitative approach, comprising theoretical review and case study, from the analysis of two examples: the actions of the Portuguese Government regarding the project "Tourism 4.0" and the Spanish Government with "Smart Tourism Destinations".

The analysis of the documents was based on the reference on public policy analysis, with attention to the models of institutional and systemic orientation and the cycle of public policies (Souza, 2006; Frey, 2000; Araújo; Rodrigues, 2017) on the possibilities of innovation for tourism (Brandão, 2014), the typologies of innovation cited by the OECD/EUROSTAST (1997) and the vision of democratic innovation (Smith, 2009).

Content analysis is of recurrent use in qualitative research to support the analysis of the content raised, whether oral or documentary, as well as media (Bardin, 1977).

At this stage, the work was organized into three phases: pre-analysis (first contact with the documents and quick reading to identify those that best fit the research objectives); exploration of the material (a second round of reading with the attention focused on answering the fixed questions and the established objectives from categories and

1 Smith's (2009) democratic innovation theoretical approach is an antithesis of Schumpeter's theoretical approach 
classifications) and, finally, the third phase, which consists of interpreting what was identified in the documents, identify convergences, divergences and implicit relationships (Godoy, 1995). Figure 2 presents the stages of the policy cycle grouped into four stages, which are subdivided into eight subphases, each explained in the figure itself.

Figure 2. Stages of the Policy Cycle.

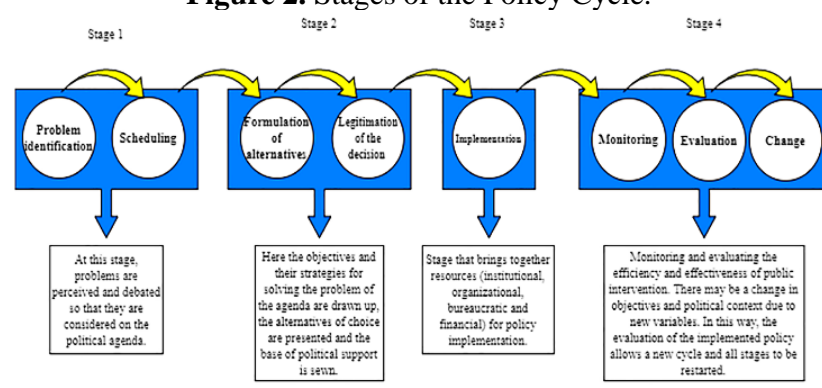

Source: prepared by the authors based on Frey (2000), Souza (2006) and Araújo and Rodrigues (2017).

To analyze the researched documents, the proposal was to merge these steps as the theoretical framework provided by institutionalism (Table 3). To this end, the analysis of the documents was carried out considering that:

In step 1 (a) the informal (socioeconomic, cultural and historical aspects) and formal (laws, policies, plans and programs existing at the time prior to the implemented innovation) institutional context was presented and, in step 1 (b), the process/pathway of change adopted was discussed.

Stage 2 of the cycle focused on the actors and the respective instances of governance that articulated the transformation of the problem into an agenda, or even which instances resulted from the entire process underway. Stage 3 sought to present the result as an established policy, and stage 4 showed how the monitoring and evaluation of this policy occurs.

\section{Results and Discussion}

The results of the analysis of the consolidation of public policy related to innovation in tourism are presented, being Tourism 4.0 in Portugal and Smart Tourism Destinations in Spain.

\section{Tourism 4.0 - Portugal}

The Government of Portugal carried out a diagnosis of the evolution of tourism activity between 2005 and 2015. In this period, Portugal recorded an average annual growth of $6.3 \%$ in international tourism revenue (Figure 3), being the second best performing country among competing European tourism destinations such as France $(1.6 \%)$, Italy $(2.2 \%)$, Greece $(2.8 \%)$, Malta $(7.4 \%)$ and Spain (2.4\%), and of Mediterranean Africa competitors such as Morocco (3.7\%), Tunisia ($3.2 \%)$ and Egypt (0\%).

Another factor highlighted in the diagnosis is related to the issuing market of tourists. The domestic market represented in 2015 approximately 33\%, while the United Kingdom, Germany, Spain, Netherlands and France represented $47 \%$ of the international market, i.e., markets very close in relation to distance and ease of land and air travel.

Figure 3. Tourism revenue in value and as a $\%$ of GDP.

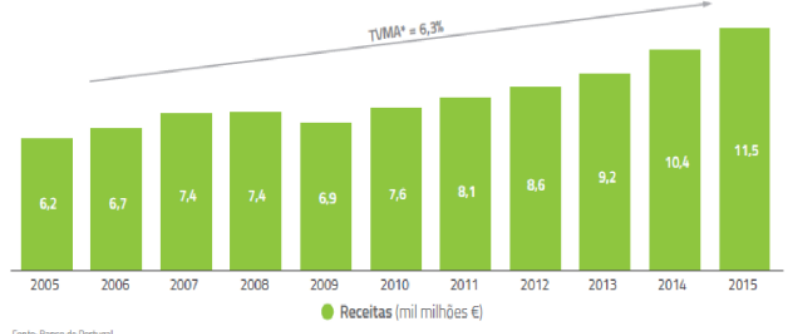

Source: Portugal/Turismo de Portugal (2017b, p. 23).

Table 4 represents the synthesis of the analysis carried out between 2005 and 2015 .

Table 3. Analysis strategy

\begin{tabular}{|c|c|c|}
\hline STEPS & SUBSTEPS & ANALYSIS \\
\hline \multirow[t]{2}{*}{$\begin{array}{l}1 \\
\text { Problem Identification and } \\
\text { Scheduling }\end{array}$} & Step 1 (a) Institutional Context & $\begin{array}{l}\text { Informal (habits, culture, new, recurrent or repressed } \\
\text { demands). } \\
\text { Formal (laws, policies, plans, programs, projects). }\end{array}$ \\
\hline & Step 1 (b) Process & $\begin{array}{l}\text { Decision-making pathway (disruptive or incremental/path } \\
\text { dependence, cabinet-based, with participation). }\end{array}$ \\
\hline $\begin{array}{l}2 \\
\text { Formulation of Alternatives } \\
\text { and Legitimation of } \\
\text { Decisions }\end{array}$ & $\begin{array}{l}\text { The policy network (institutional arrangements or } \\
\text { governance structures) }\end{array}$ & $\begin{array}{l}\text { Interaction of the different institutions, groups of actors } \\
\text { (politicians or bureaucrats) and institutions responsible for } \\
\text { holding discussions to formulate the alternatives }\end{array}$ \\
\hline $\begin{array}{l}3 \\
\text { Implementation }\end{array}$ & $\begin{array}{l}\text { Pooling of bureaucratic, organizational, financial } \\
\text { and institutional resources to achieve the outcome }\end{array}$ & The specific policy \\
\hline $\begin{array}{l}4 \\
\text { Evaluation }\end{array}$ & Monitoring, Evaluation and Change & $\begin{array}{l}\text { Evaluate the effectiveness of the policy as the scenario } \\
\text { changes. Start the cycle over again }\end{array}$ \\
\hline
\end{tabular}


Table 4. Positive factors of the project Positive Factors $\quad$ Aspects to be Improved

\begin{tabular}{|c|c|}
\hline Positive Factors & Aspects to be Improved \\
\hline $\begin{array}{l}\text { More qualified territory and } \\
\text { tourism resources }\end{array}$ & Capitalization of companies \\
\hline $\begin{array}{c}\text { Infrastructure to support } \\
\text { development }\end{array}$ & $\begin{array}{c}\text { Qualification of human } \\
\text { resources }\end{array}$ \\
\hline $\begin{array}{c}\text { Growth in several indicators of } \\
\text { tourism demand }\end{array}$ & Income of workers in tourism \\
\hline $\begin{array}{l}\text { More qualified supply of } \\
\text { accommodation }\end{array}$ & $\begin{array}{l}\text { Bureaucracy and context } \\
\text { costs }\end{array}$ \\
\hline $\begin{array}{c}\text { New forms of more qualified } \\
\text { accommodation }\end{array}$ & $\begin{array}{c}\text { Digitalisation of the tourism } \\
\text { offer }\end{array}$ \\
\hline $\begin{array}{c}\text { Creative entrepreneurship on } \\
\text { the rise }\end{array}$ & Seasonality \\
\hline $\begin{array}{c}\text { Increase in the supply of tourist } \\
\text { entertainment activities }\end{array}$ & Regional asymmetries \\
\hline $\begin{array}{c}\text { International recognitions and } \\
\text { awards in several areas of } \\
\text { tourism in Portugal }\end{array}$ & $\begin{array}{l}\text { Information on Portugal in } \\
\text { foreign markets }\end{array}$ \\
\hline \multirow[t]{2}{*}{ Increased air connections } & $\begin{array}{c}\text { Networking and joint } \\
\text { promotion and co-creation }\end{array}$ \\
\hline & $\begin{array}{l}\text { Sustainability of the } \\
\text { destination and of the } \\
\text { companies }\end{array}$ \\
\hline
\end{tabular}

With the results, a process of public participation and discussion on the challenges, objectives and goals took place on May 24, 2016. The Resolution of the Council of Ministers No. 134/2017, published in the Diário da República ${ }^{2}$ on September 27, 2017 approved the "Strategy for Tourism 2027 (ET27)" (Portugal; Presidency of the Council of Ministers, 2017).

The strategy adopted aimed to ensure the consolidation of sustainable tourism activity throughout the year and throughout the Portuguese territory, "that enhances the natural resources that Portugal has and that contributes to job and wealth creation and the promotion of territorial and social cohesion".

The construction of the Tourism Strategy 2027 (TE27) was guided by a process that involved a wide participation of tourism agents and civil society starting on May 24, 2016 in the Municipality of Tomar, $140 \mathrm{~km}$ from Lisbon. They used the proposal of looking out of the box $(\mathrm{OOB})^{3}$ in order to gather contributions from various angles of society. According to Cordeiro and Nogueira (2018, p. 2) OOB represents "[...] the creation of a virtual environment where knowledge is acquired in a way based on constructivism".

This process ran until January 6, 2017 and included different forms of public consultation tourism strategic laboratories (TSLs), international focus groups, website and technological platforms, opinions and written contributions from various public and private entities and individual citizens, involving a total of more than 1,700 participants.

The TSEs held public sessions in all the regions of Portugal with the aim of obtaining contributions and recommendations for tourism, analyzing the main tourism indicators of each region, debating around the strategic priorities for regional and national tourism. Ten public sessions were held with over 1,400 participants, with a more transversal vision discussing international trends and agenda, competitiveness and innovation in tourism and knowledge, employment and training. Five main challenges highlighted by the participants were identified, among them the stimulation of innovation and entrepreneurship.

TE27 was structured in five strategic axes, namely: i. Enhancing the territory and communities; ii. Boosting the economy; iii. Enhancing knowledge; iv. Generate connectivity networks; and v. Portugal Project. Each axis has, hierarchically, lines of action and typologies (Portugal; Presidency of the Council of Ministers, 2017).

Some aspects to highlight in SL27 about the insertion of Small and Micro Enterprises (SMEs), entrepreneurship and innovation in tourism. SMEs were mentioned in Axis 2 - Boosting the economy as typology: Availability of aggregated information on financing and capitalization solutions for SMES and; in Axis 3 - Boosting knowledge as typology: Projects to develop the strategic and competitive management capabilities of SMES, including, namely, adaptation to new business models, access to international markets and to the digital economy (ibidem, our emphasis).

Entrepreneurship was mentioned in Axis 2 Boosting the economy as a line of action: To affirm Portugal as an international reference hub in innovation, entrepreneurship and production of goods and services for tourism with two typologies Projects to encourage the development and growth of start-ups, innovation and entrepreneurship activities in tourism and Initiatives to boost entrepreneurship, including, namely, the following components (Incubation and acceleration of companies; National Network of Tourism Incubators; Support for internationalization of

2 https://dre.pt/web/guest/home/-/dre/108219721/details/maximized?serie=I\&dreId=108219717

3 It is a metaphor that means to think differently, unconventionally or from a new perspective (HAKAK et al., 2016). 
Figure 4. relevant companies and institutions in the construction of the Portugal i4.0 initiative

\begin{tabular}{|c|c|c|}
\hline $\begin{array}{l}\text { Deloltte. ANN } \\
\text { Google SIEMENS }\end{array}$ & 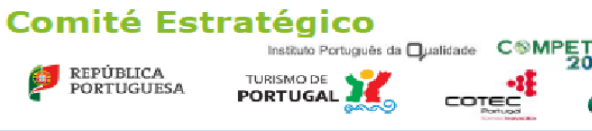 & Microsoft @ Q Naltice. BP \\
\hline 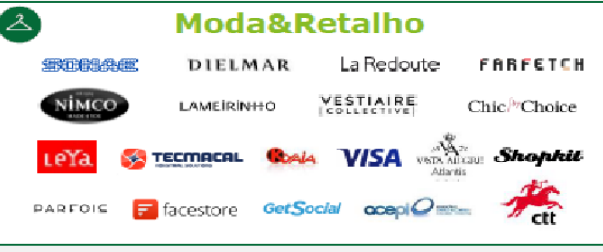 & 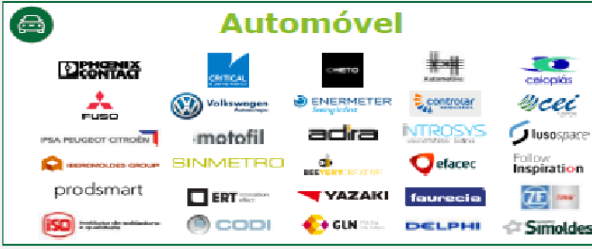 & 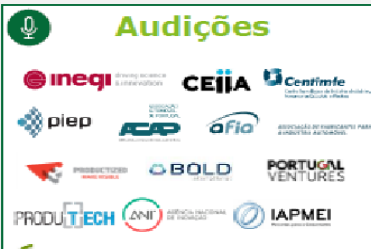 \\
\hline 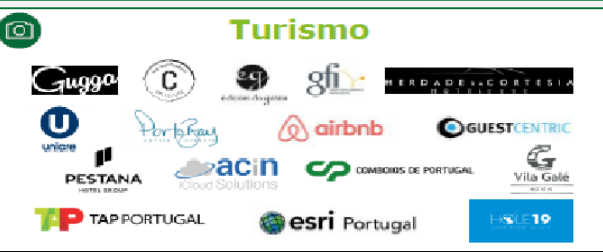 & 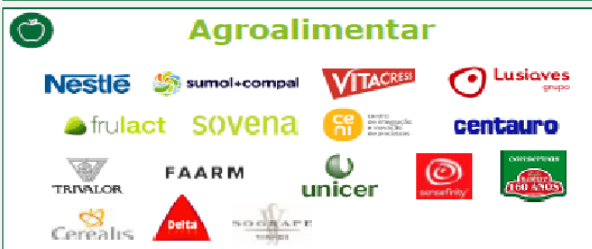 & 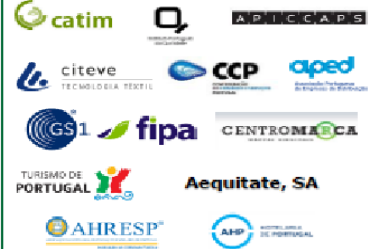 \\
\hline
\end{tabular}

companies - participation in international fairs; and Entrepreneurship Programme in Tourism for students in Hotel and Tourism Schools) (ibidem, our emphasis).

Complementing this, entrepreneurship is referenced in Axis 3 - Enhancing knowledge as a typology: Boosting the Schools of Hospitality and Tourism of the Tourism of Portugal as Specialized Training Centers in Tourism, Entrepreneurship and with an international vocation (ibidem, our emphasis).

In relation to innovation, it was quoted in Axis 2 Boosting the economy as a line of action: To affirm Portugal as an international reference hub in innovation, entrepreneurship and the production of goods and services for tourism and typology Projects to encourage the development and growth of start-ups, innovation and entrepreneurship activities in tourism and Stimulating financial innovation instruments in tourism such as venture capital funds and other specific financial instruments for tourism (ibidem, our emphasis).

In Axis 3 - Enhancing knowledge, innovation is cited in the typologies: Open Kitchen Fab Labs opening Schools of Hospitality and Tourism to companies and startups for product testing and fostering creativity and innovation in gastronomy and catering and Stimulating an ecosystem of continuous innovation in tourism and international reference, which includes the creation of a Tourism Innovation Centre based on a partnership between the Tourism of Portugal, associative structures, companies, entities of the entrepreneurial ecosystem and creative industries and technology partners (ibidem, our emphasis).
The synthesis of the relation observed in TE27 between SMEs, entrepreneurship and innovation is in the economic boost of Portugal observing the digital transformation. The digital transformation has been consolidated since 2017 with the Portugal i4.0 (Industry 4.0) Initiative. More than 100 entrepreneurs and relevant institutions from Portugal participated, represented in Figure 4.

The Portuguese Ministry of Economy identified the opportunity to generate conditions for the development of national industry and services in the digital era in four areas defined as strategic: Automotive, Fashion and Retail, Agro-Food and Tourism, selected from the importance to the national economy, relevance of SMEs and special disposition to digital transformation, as development of cyber-physical technologies that allow disruptive changes in production and business models (ibidem, our emphasis).

In 2017, the Tourism 4.0 Programme emerged with the aim of transforming Portugal into a global hub of innovation in tourism, promoting an ecosystem of technological and business cooperation, fostering entrepreneurship (a vehicle for innovation and the creation of new companies), knowledge transfer from companies in the sector, leadership in innovation processes (the future of tourism), training and empowerment of human resources and companies to innovate. The programme included incubation, acceleration, investment and internationalization actions, initially for over 200 companies (Portugal: Turismo de Portugal, 2017c).

Table 5 represents the programme overview divided into four strategic areas namely: i. Digital tourism platform, ii. Technological and business cooperation ecosystem, iii. Support and incentive 
vehicles and iv. Other initiatives that interact with the tourism plan.

Table 5. Overview of the Tourism 4.0 Programme

\begin{tabular}{|c|c|}
\hline \multirow{3}{*}{$\begin{array}{l}\text { Digital Tourism } \\
\text { Platform }\end{array}$} & Creation of an i4.0 maturity assessment matrix \\
\hline & $\begin{array}{l}\text { Digital Tourism Forum: events to spread } \\
\text { digitalisation in the tourism sector }\end{array}$ \\
\hline & $\begin{array}{l}\text { International promotion of Portuguese best } \\
\text { practices and initiatives in the tourism sector }\end{array}$ \\
\hline \multirow{3}{*}{$\begin{array}{l}\text { Ecosystem of } \\
\text { technological } \\
\text { and business } \\
\text { cooperation }\end{array}$} & $\begin{array}{l}\text { Boosting the ecosystem: i. Digital one-stop } \\
\text { shop for interaction between tourism sector } \\
\text { companies and the State; ii. Integrative platform } \\
\text { of data and interest for tourism businesses }\end{array}$ \\
\hline & $\begin{array}{l}\text { Uniformization of destination Portugal's } \\
\text { communication on public digital platforms }\end{array}$ \\
\hline & $\begin{array}{l}\text { Start-ups: i. Tourism Innovation Centre and ii. } \\
\text { Digital Tourism Hackathon }\end{array}$ \\
\hline \multirow{3}{*}{$\begin{array}{l}\text { Support and } \\
\text { incentive } \\
\text { vehicles }\end{array}$} & $\begin{array}{l}\text { Financing and investment incentives: i. } \\
\text { Mobilizing programmes for research and } \\
\text { technological development; ii. Accelerator for } \\
\text { incentive competitions to digitisation in } \\
\text { tourism; iii. Vale i } 4.0 \text { for Micro and Small and } \\
\text { Medium Enterprises (SMEs) }\end{array}$ \\
\hline & $\begin{array}{l}\text { Training and empowerment of human } \\
\text { resources: i. Tourism Digital Academy; ii. } \\
\text { Creation of training in i4.0 at Universities, } \\
\text { Polytechnic Institutes and Hotel and Tourism } \\
\text { Schools; }\end{array}$ \\
\hline & $\begin{array}{l}\text { Legal and regulatory adaptation: } \\
\text { standardisation for Industry } 4.0\end{array}$ \\
\hline $\begin{array}{l}\text { Other initiatives } \\
\text { that interact } \\
\text { with the tourism } \\
\text { plan }\end{array}$ & $\begin{array}{l}\text { Sustained expansion of the wi-fi network in } \\
\text { historic city centres }\end{array}$ \\
\hline
\end{tabular}

It is important to highlight that for the implementation of the proposals of the Tourism 4.0 Program there is the involvement of different public and private entities such as:

- Ministry of Economy and Employment;

- State Secretariat of Tourism;

- Turismo de Portugal. national tourism authority;

- COTEC Portugal ${ }^{4}$, the main business association for the promotion of innovation and business technological cooperation that includes multinational companies, national companies and SMEs from different economic sectors; and

- IAPMEI Agency for Competitiveness and Innovation ${ }^{5}$ : its mission is to promote competitiveness and business growth, aiming at strengthening innovation, entrepreneurship and business investment.

Finally, the management and monitoring process of TE27 and consecutively of the Tourism 4.0 Programme is structured on three bases, Turismo de Portugal, Strategic Tourism Laboratories
(STLs) implemented in all tourism regions and by the National Tourism Forum.

\section{Smart Tourism Destinations - STD - Spain}

The strengthening of the process of tourism innovation in Spain emerges in November 2007 when the Spanish Government approves in the Council of Ministers the Spanish Tourism Plan Horizonte 2020 (Plan del Turismo Español Horizonte 2020). At that time, the Vice-President of the Spanish Government, Mrs. María Teresa Fernández de la Veja, pointed out that the plan intended to increase social and economic benefits, diversify tourist activity generating prosperity and progress for the whole Spanish society. And stressed that tourism was a fundamental pillar for the growth and development of the economy of Spain (Spain; Presidency of the Gobierno, 2007).

For the preparation of the Spanish Tourism Plan Horizon 2020 there was a broad participation of civil society, public and private sector in the area of tourism in Spain, surveys in the main issuing markets of international tourists to Spain and with foreign tourists, described in Table 6 .

Table 6. Phases II of the plan: participation and debate

\begin{tabular}{|c|c|}
\hline Focus & Shares \\
\hline $\begin{array}{c}\text { Civil } \\
\text { Society }\end{array}$ & $\begin{array}{l}\text { Focus groups were conducted in two representative } \\
\text { tourist destinations such as Calviá (Mallorca) and } \\
\text { Barcelona, as well as surveys of more than } 1,000 \\
\text { residents in different cities and online discussion } \\
\text { forums. }\end{array}$ \\
\hline $\begin{array}{l}\text { Public and } \\
\text { Private } \\
\text { Sector }\end{array}$ & $\begin{array}{l}\text { Meetings held in Barcelona, Madrid, Jerez de la } \\
\text { Frontera, Gijón, Palma de Mallorca and the Canary } \\
\text { Islands with more than } 1,600 \text { representatives of the } \\
\text { sector and an online survey that obtained more than } \\
2,200 \text { responses. }\end{array}$ \\
\hline $\begin{array}{c}\text { Main } \\
\text { source } \\
\text { markets }\end{array}$ & $\begin{array}{l}\text { Analysis of over } 12,000 \text { questionnaires applied in } \\
\text { the main issuing markets carried out by Turespaña } 6 \\
\text { and discussions with } 72 \text { groups held in } 18 \text { European } \\
\text { cities. }\end{array}$ \\
\hline Tourists & $\begin{array}{l}\text { More than } 25,000 \text { loyalty and satisfaction surveys } \\
\text { conducted by Frontur }^{7}\end{array}$ \\
\hline
\end{tabular}

The plan was already highlighting the importance of public policies, SMEs and innovation. Increasing tourism leadership depends on the cooperation between the public sector and the participation of the private sector in the definition of public policies with an impact on tourism. It is important to highlight that Spain is the most competitive country in tourism by the World Economic Forum WEF (2019) and among the top 3 in numbers of international tourists and tourism revenue by the studies of the World Tourism Organization UNWTO (2020).

\footnotetext{
4 https://cotecportugal.pt/pt/quem-somos/

5 https://www.iapmei.pt/getattachment/SOBRE-O-IAPMEI/Missao-Visao-Valores/Decreto-Lei-n\%C2\%BA-266-2012-(Organica-do-IAPMEI).pdf.aspx 6 Turespaña.

https://www.tourspain.es/_layouts/15/Tourspain/registroUsuarios/login.aspx?ReturnUrl=\%2f_layouts\%2f15\%2fTourSpain\%2fregistrousuarios\%2fmisutilidades.aspx

7 Frontur. Available at https://www.dataestur.es/general/frontur/
} 
As for SMEs, the analysis carried out highlighted their representativeness in the tourism market in the generation of jobs and their resilience (ability to adapt to change). On the other hand, they point out the difficulties to retain talent and to innovate, so they described the role of the State in leading the process to boost innovation for tourism SMEs, citing, for example, the National Plan of $\mathrm{R}+\mathrm{D}+\mathrm{I}$ (Spain; Ministry of Industry, Tourism and Commerce, 2007b).

In relation to innovation they highlighted as strategic issues from the vision of the new tourism economy (based on innovation, knowledge and talent) namely (Spain; Ministry of Industry, Tourism and Commerce, 2007b):

i. improving the competitive environment, especially in terms of employment and training, productivity and research \& development \& innovation;

ii. the difficulty in attracting and retaining the best professionals (determining factors for improving the quality perceived by customers);

iii. the inadequate management of knowledge and innovation by both business management and tourist destinations; and

iv. inadequate management model with scarcity of motivation and resources for innovation.

Table 7 presents a summary of the discussion of innovation in relation to tourism referring to the Spanish Tourism Plan Horizon 2020.

Table 7. Summary of the discussions on innovation and tourism

\begin{tabular}{|c|c|}
\hline Focus & Reflection \\
\hline $\begin{array}{l}\text { Culture of } \\
\text { innovation }\end{array}$ & $\begin{array}{l}\text { Spanish tourism needs to consolidate a culture of } \\
\text { innovation in businesses and destinations, allowing } \\
\text { R\&D\&I to consolidate values for permanent } \\
\text { improvement in planning, policy-making and the } \\
\text { provision of tourism services. The different public and } \\
\text { private agents should explicitly evidence their } \\
\text { commitment to this. }\end{array}$ \\
\hline $\begin{array}{c}\text { Value } \\
\text { Creation }\end{array}$ & $\begin{array}{l}\text { Innovation in tourism materializes in the processes of } \\
\text { value creation and continuous improvement aimed at the } \\
\text { customer, and the improvement of products and } \\
\text { experiences that can offer, in addition to improving } \\
\text { business processes, in the preservation and sustainability } \\
\text { of the environment in which tourism activity is } \\
\text { developed. }\end{array}$ \\
\hline $\begin{array}{c}\text { Knowledge } \\
\text { Network }\end{array}$ & $\begin{array}{l}\text { The generation of new tourism knowledge will be } \\
\text { effective and efficient to the extent that as many } \\
\text { representatives of the different areas, sectors and } \\
\text { territories involved as possible participate. The goal is to } \\
\text { create a knowledge management and tourism innovation } \\
\text { network. }\end{array}$ \\
\hline New model & $\begin{array}{l}\text { Boost a new horizontal innovation model for the tourism } \\
\text { sector, improving scientific and technological capacity, } \\
\text { and increasing effectiveness and efficiency in } \\
\text { management processes. }\end{array}$ \\
\hline
\end{tabular}

8 SEGITTUR. Available at: https://www.segittur.es/ejes-de-actuacion/
In 2012 the Spanish Government presents the National and Integral Tourism Plan (Plan Nacional e Integral de Turismo) NITP which aimed to boost the competitiveness of tourism businesses and destinations, renew leadership in the world tourism market for the next decades and contribute to the generation of wealth, employment and wellbeing of citizens (Spain; Ministry of Industry, Energy y Tourism, 2012).

In the plan it is highlighted as strategic to establish mechanisms that enable the faster incorporation of innovations with the definition of a homogeneous framework that allows the analysis of tourist destinations under the concept of "Smart

Destinations" in line with the trends of creating "Smart Cities".

The State Society for the Management of Innovation and Tourism Technologies (Sociedad Estatal para la Gestión de la Innovación y las Tecnologías Turísticas - SEGITTUR ${ }^{8}$ ) would be responsible for the construction of a methodology that includes the necessary requirements to qualify a destination as smart, with the participation of universities, business schools and research centers, as well as the public and private sector in the areas of tourism, economic development, mobility, environment, provision of tourism services, among others (Spain; Ministry of Industry, Energy y Tourism, 2012).

As established measures were: i. the elaboration of a base document for the definition of "smart destinations" and its minimum requirements to be met; ii. the specific definition for qualification of "smart destinations" and; iii. the choice of pilot projects of qualification.

In December 2017 the Spanish Government launches the National Plan for Smart Territories (Plan Nacional de Territorios Inteligentes Diciembre 2017) whose purpose is to address problems of city management rather than the tourism industry. They focused on five priority areas among them, smart tourism (Spain; Ministry of Industry, Energy, Tourism y Agenda Digity, 2017).

The document mentions that the traditional conceptions of smart city to smart territory have been converted to adopt the best technology continuously to increase the efficiency of the management of public services and ensure the maximum satisfaction of visitors (tourism demands different types of services and infrastructure of the city and businesses) (Spain; Ministry of Industry, Energy, Tourism y Agenda Digity, 2017). 
An important highlight is the vision of tourism innovation ecosystem as the basis for smart tourism. That is, the need to promote the relationship between public managers and the technology industry, and the impacts for SMEs (Spain; Ministry of Industry, Energy, Tourism y Agenda Digity, 2017, emphasis added).

As a result, SEGITTUR consolidates the concept of smart tourism destinations based on the vision of governance, innovation, technology, sustainability and accessibility represented in Figure 5.

Figure 5. Conceptual vision of smart tourism destinations.

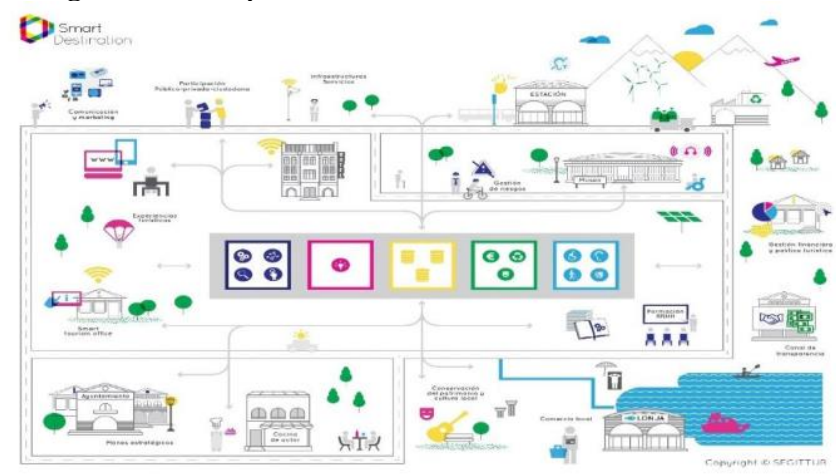

Source: SEGITTUR (2017).

SEGITTUR contextualizes STD as being

An innovative tourist destination, consolidated on a state-ofthe-art technological infrastructure, which ensures the sustainable development of the tourist territory, accessible to all, which facilitates the interaction and integration of the visitor with the surroundings and increases the quality of their experience at the destination and improves the quality of life of the resident (SEGITTUR, 2017).

The transformation of a tourism destination into a STD aims at revaluing the tourism destination through innovation and technology by:

- Increased competitiveness with better use of tourism resources;

- Improved efficiency in production and marketing processes;

- Impulse for the sustainable development of the destination in three aspects: environmental, economic and sociocultural;

- Improving the quality of visitors' stay and the quality of life of residents; and

- Consolidate the tourism strategy as a basis for the economic dynamization of the territory ensuring its positive effects in the long term.

To this end, technical standards were created to create a homogeneous framework for the STD project aligned with the process of creating smart cities being UNE 178501:2018 Sistema de Gestión de un Destino Turístico Inteligente, UNE 178502:2018 Indicadores $y$ herramientas del Destino Turísticos Inteligentes, UNE 178503:2019 Semántica aplicada a los destinos inteligentes and UNE 178503:2019 del Hotel Digital inteligente y conectado.

Consolidating the STD process was the formation of the Network of Smart Tourism Destinations (RED DTI) in October 2018 with about 70 members. In 2019 there was a revision of the bylaws that allowed an expansion of new members. Data from May 2021 indicated more than 250 members from tourist destinations, institutions and companies (SEGITTUR, 2021).

Finally, destinations that integrate the STD Network benefit in: i. the formation of strategic alliances that are consolidated between destinations and the private sector for the development of technologies and tourism innovations; ii. the assistance service in the implementation of the conversion process in STD; iii. advice on standardization and the implementation of seals as Integral System of Spanish Tourism Quality in destinations; iv. access to databases of support, subsidies and funding; v. training programs and training in matters related to the axes of the STD methodology; vi. catalog of suppliers of technological solutions and services for destinations, vii. news service and repository of studies and publication; viii. presence and participation in fairs and national and international forums and other networks (SEGITTUR, 2021).

Table 8 presents an analysis of the research conducted from the institutionalist approach in the context of public policies, type of innovation and a summary of the cases.

With regard to the Portuguese case, the institutional context, in the problem and scheduling stage (Stage 1), was favorable in the sense that the country had a history of growth in tourism revenues over a decade. However, even so, they established a diagnostic analysis and identified tourism as strategic for the country's economy and, furthermore, that certain aspects needed to be contested in order to achieve a more competitive scenario. The chosen process was based on citizen participation through public 
Table 8. Analysis of institutionalist approaches, types of innovation and innovation policy

\begin{tabular}{|c|c|c|c|}
\hline Case & $\begin{array}{c}\text { Institutionalist } \\
\text { Approach }\end{array}$ & $\begin{array}{c}\text { Type of } \\
\text { Innovation } \\
\end{array}$ & Overview \\
\hline $\begin{array}{c}\text { Tourism } 4.0 \\
\text { Portugal }\end{array}$ & $\begin{array}{l}\text { Contemporary } \\
\text { Institutionalist }\end{array}$ & Organizational & $\begin{array}{l}\text { National policy from the Ministry of Economy for digital transformation of strategic } \\
\text { areas for the development of Portugal, in which tourism is contemplated. The } \\
\text { innovation policy focuses on the development of digital tourism platform, } \\
\text { development of technological and business cooperation ecosystem (strengthening } \\
\text { SMEs), political and financial support and incentive and integration with the national } \\
\text { tourism plan. }\end{array}$ \\
\hline $\begin{array}{c}\text { Smart } \\
\text { Tourism } \\
\text { Destination } \\
\text { Spain }\end{array}$ & $\begin{array}{l}\text { Contemporary } \\
\text { Institutionalist }\end{array}$ & Organizational & $\begin{array}{l}\text { National policy in the construction of intelligent territories aimed at addressing } \\
\text { management problems in cities where tourism, as a strategic sector of socio- } \\
\text { economic development in Spain, has been contemplated. The innovation policy is } \\
\text { based on the vision of a tourism innovation ecosystem aimed at improving } \\
\text { competitiveness (strengthening SMEs), process efficiency, sustainable development, } \\
\text { quality of life for residents and tourists, and economic dynamism of the territory. }\end{array}$ \\
\hline
\end{tabular}

consultations that extended over a period of nine months.

It also highlights institutional innovation with the creation of standards and rules and, again, organizational innovation with the creation of the STD Network, process innovation (how to constitute a STD) and product innovation. Democratic innovation was also present as in the Portuguese model, since citizen participation was enhanced through various channels.

In the document analysis, Stage 2 is clearly defined, since the networks of actors were activated and different institutions interacted, with the purpose of legitimizing the problems and the alternatives chosen to solve them. In all, five different strategies were established to interact with the network of actors. The chosen methodology, named out of the box (OOB), should be highlighted, as it imprinted an innovative character to the process of building the desired policy.

As for Stage 3 (implementation) resulted in the construction and implementation of the "Tourism Strategy 2027". This policy indicated the importance of small and medium enterprises, entrepreneurship and innovation. In addition, emphasis is given to the Tourism 4.0 Program.

Finally, Stage 4 (evaluation and monitoring), is supported by three governance bodies: Turismo de Portugal, Strategic Tourism Laboratories (for each region of the country) and the National Tourism Forum.

From the analysis of the Portuguese experience, the complete cycle of creation and implementation of a public policy was verified. In addition, it was identified innovation along each stage of the cycle in the following modalities: process, organizational, marketing, democratic and product.

In the Spanish case, the institutional context (Stage 1a) for change and innovation emerges ten years earlier than in Portugal, with the Spanish
Tourism Plan Horizon 2020 and considering that the activity was an important pillar for the country's economy.

Despite the acknowledgement of public actors on the importance of the sector, there was, as in Portugal, a process (Stage 1b) with wide consultation of society through digital platforms, focus groups, meetings with representatives of sectoral groups and online discussion forums. This scenario allows us to identify incremental innovation in the process (stage $1 \mathrm{~b}$ of the cycle), since Spain was already leading the sector at a global level.

The stage of formulating alternatives (Stage 2) counted on the opinion of actors from civil society, public sector, private initiative, the issuing market and tourists. As a strategic focus, the country defined as a priority in the area of tourism: public policies, innovation and small and medium enterprises, understanding that the three issues were dependent on each other.

As for the implementation (Stage 3), the result of the process reflected on the evolution of the discussion considering innovation as culture, value, knowledge and model, preparing the ground for the birth of the National and Integral Tourism Plan (2012). What is considered another example of the incremental model of innovation in Spanish public policies.

This plan warned about the importance of a "model" for smart management of destinations. To support the plan, an official governance structure was established, an example of organizational innovation, called Segittur. In 2017, the National Plan for Smart Territories was launched, extrapolating the tourism segment and incorporating the integral management of cities. The stage of evaluation, monitoring and change (Stage 4) occurred recurrently in the Spanish model, since between 2007 and 2017 the emergence, expansion or reformulation of plans 
was noted as a function of other pre-existing ones (incremental innovation).

\section{Concluding remarks}

The documentary analysis carried out from the Portuguese/Spanish cases and using the chosen theoretical scope, allowed reflecting on innovation as a process of construction of a public policy and, also, as a result of it.

Comparing the two models it was found that both have coinciding elements in what concerns the understanding of the importance of public policies for innovation, the presence of governance structures for the management and control of these policies and the stimulus to small and medium enterprises.

It is concluded that in both cases innovation is transversal and, like tourism, depends on the alignment of different areas. For this, policies and plans need to reflect concepts increasingly integrative and systemic with other sectors, as did the National Plan of Smart Territories (Spain), characterizing a reverse innovation of the community, since innovation in tourism brought benefits to the management of the city as a whole (BRANDÃO, 2014).

It became evident that tourism and innovation for tourism, in both countries, are issues of strategic vision of the state and not of the government. The cases studied offer a lens to look at the planning of Brazilian tourism at the federal, state and municipal levels and note that actions in Brazil are still incipient. However, one should highlight the proposal of the Ministry of Tourism in the construction of a project to transform, initially, ten tourist cities into innovative destinations from an adaptation of the Spanish methodology in partnership with the Argentinean institute Ciudades del Futuro (ICF). This project includes Rio Branco (AC) and Palmas (TO) representing the North region, Recife (PE) and Salvador (BA) in the Northeast region, Campo Grande (MS) and Brasília (DF) in the Midwest region, Florianópolis (SC) and Curitiba (PR) in the South and Rio de Janeiro (RJ) in the Southeast (MTur, 2021).

Finally, looking at the trajectories of Portugal and Spain and considering that the trajectory matters, according to the institutionalist vision, it is clear that the path to innovate requires specific public policies. And even if such policies are incremental, and not disruptive, they should be based on a strongly integrative, participatory and shared vision of the future with the largest possible number of actors.

\section{References}

Alban, M. (2021). The Unsustainability of Tourism in Brazil and the Success of Praia do Forte: an exploratory analysis based on the new institutional economy. Turismo em Análise, v.19, n.1.

Araújo, L., \& Rodrigues, M. L. (2017). Models of public policy analysis. Sociology, Problems and Practices, n. 83, p. 11-35, 2017. DOI:10.7458/SPP2017839969

Arruda, D. O., Mariani, M. A. P., \& Caleman, S. M. Q. (2014). Coordinación y estructura de gobernanza en un sistema productivo de turismo. Estudios y Perspectivas en Turismo. Volumen 23, pp.343 361.

Baggio, R., Scott, N., \& Cooper, C. (2010). Improving tourism destination governance: a complexity science approach. Tourism Review, v. 65, n. 4, p. 51-60,

2010. https://doi.org/10.1108/16605371011093863

Baptista, J. M. L., Pocinho, M., \& Nechita, F. (2021). Tourism and Public Policy. Bulletin of the Transilvania University of Braşov Series V: Economic Sciences, v. 12, n. 1, 2019. Available at: https://doi.org/10.31926/but.es.2019.12.61.1.11. Access on: 20 Mar.

Bardin, L. (1977). Content analysis. Lisboa: Edições 70.

Bauman, Z. (2007). Tempos Líquidos. [Translation Carlos Alberto Medeiros]. Rio de Janeiro: Jorge Zahar Ed.

Baumgartner, F. R., \& Jones, B. D. (1999). Punctuated equilibrium theory: explaining stability and change inAmerican policymaking. In: SABATIER, P.A. Theories ofthe policyprocess. Oxford: Westview Press.

Beni, M. C. \& Moesch, M. M. (2017). A teoria da complexidade e o ecossistema do turismo. Turismo - Visão e Ação, Balneário Camboriú, 19(3), p. 430-457. DOI: https://dx.doi.org/10.14210/rtva.v19n3.p430-457.

Beni, M. C. (1998). O conceito de sustentabilidade na política de turismo e meio ambiente. Revista de Administra\&ccdeil; ão da Universidade de São Paulo, 33(4).

Boullón, R. C. (1997). Planificación del espacio turístico. (3 Ed). México: Trillas.

Brandão, A. F. A. (2014). Inovação em Turismo: O Papel dos Sistemas Regionais de Inovação. Tese (Doutoramento em Turismo). Universidade de Aveiro: Aveiro.

Butler, R. W. (1980). The concepto f a tourism area cycle of evolution and implications for management. The Canadian Geographer, v. 24, n. 1, p. 5-12. 
Cavalcante, C. M. (2014). Institutional economics and the three dimensions of institutions. Rev. Econ. Contemp., Rio de Janeiro, v. 18, n. 3, p. 373-392, sep-dez.

Chang, H. J. (2002). Breaking the mould: an institutionalist political economy alternative to neo-liberal theory of the market and the state. Cambridge Journal of Economics, v. 26, n. 5, p. 539-559, Sept. 2002. https://www.jstor.org/stable/23600312.

Chang, H. J., \& Evans, P. (2005). The role of institutions in Economic Change. In: DYMSKI, G.; PAUL, S. (Eds.) Re-imagining Growth. London: Zed Press, p. 99-140.

Chechi, L. A., \& Grisa, C. (2019). Institutionalist Approaches and the Contributions in Public Policy Analysis. Journal of Public Policy, v. 23, n. 2 , p. $735-753, \quad 2019 . \quad$ DOI: http://dx.doi.org/10.18764/2178-2865.v23n2p735753.

Coase, R. H. (1937). The nature of the firm. Economica, New Series, v. 4, n. 16, p. 386-495, nov. 1937. Disponível em: http://links.jstor.org/sici?sici $=0013$ 0427\%28193711\%292\%3A4\%3A16\%3C386\%3AT NOTF\%3E2.0.CO\%3B2-B

Commons, J. (1931). Institutional economics. American Economic Review, v. 21, p. 648-657, 1931. Available at: https://econpapers.repec.org/article/hayhetart/co mmons1931.htm. Accessed on: 22 mar.

Conceição, O. A. C. O. (2002). Conceito de Instituição nas Modernas Abordagens Institucionalistas. Economia Contemporânea, Rio de Janeiro, v. 6, n. 2, p. 119-146, jul./dez.

Cooper, C., Bedar, F., Duguay, B., Hawkins, D., Khomsi, M. R., Mata, J., \& Perdomo, Y. (2019). Case Studies Sociocultural Innovation. In. E. FayosSolà, C. Cooper (eds). The Future of Tourism: Innovation and Sustainability. Springer International Publishing.

Cordeiro, J. V. M. N., \& Nogueira, R. R. O. (2018). (Out of the box): a virtual environment based on the constructivist philosophy. South Brazilian Congress of Computing (9:: 2018: Criciúma, SC). [Proceedings of the] IX South Brazilian Congress of Computing - 9 SULCOMP [electronic resource], VIII Academic Papers Workshop, October 3-6, 2018. - Criciúma: UNESC, 2018. Available at: http://periodicos.unesc.net/sulcomp/article/view/4 805/4395. Accessed on: 10 abr.

Costa, H. A., \& Souto Maior, A. (2006). Sistemas produtivos locais em turismo: relacionamentos estratégicos e aglomeração territorial como vantagens competitivas. Observatório de Inovação do Turismo - Revista Acadêmica, v. 1, n. 1 aug., $\quad$ p. $1-22, \quad 2006$. https://bibliotecadigital.fgv.br/ojs/index.php/oit/ar $\underline{\text { ticle/view/5608/4329 }}$

Cuervo, R. (1967). Estudios y desarrollo de las zonas turísticas. Cuadernos Técnicos de Turismo. Instituto Mexicano de Ivestigaciones Turisticas. México.

Deloitte. (2017). i4.0 Industry 4.0. 2017. Available at: https: $: / W w w 2$. deloitte.com/pt/pt/pages/consumerindustrial-products/articles/industria-4-0-.html. Accessed on: 03 Apr.

Dias, R. (2005). Introduction to Tourism. São Paulo: Atlas.

Domareski-Ruiz, T. C., Gândara, J. M., \& Chim-Miki, A. F. (2015). Destinos Turísticos como territórios de inovação: análise dos vetores de competitividade urbana à luz dos pressupostos sugeridos pela União Europeia, por meio do relatório "State of European Cities". Revista Turismo - Visão e Ação, v. 17 , n. 3 , p. 758-784, sep./dez. 2015. Doi: 10.14210/rtva.v17n3.p758-784

Dryzek, J. S. (2009). Democratization as Deliberative Capacity Building. Comparative Political Studies, v. $42, \quad$ n. $11, \quad$ p.1379-1402, 2009. doi: $10.1177 / 0010414009332129$

Dye, T. R. (2005). Understanding Public Policy. Upper Saddle, NJ: Prentice Hall.

Easton, D. (1968). A theory of political analysis. Rio de Janeiro: Zahar.

Etzioni, A. (1967). Mixed Scanning: A Third Approach to Decision-Making. Public Administration Review, v. 27, n. 5, p. 385-392, 1967. https://doi.org/10.2307/973394

Falaster, C., Zanin, L. M., \& Guerrazzi, L. (2017). "Institutional theory in tourism research: New opportunities from an evolving theory," Brazilian Journal of Tourism Research, 11(2): 270-293.

Frey, K. (2000). Políticas públicas: um debate conceitual e reflexões referentes à prática da análise de políticas públicas no Brasil. Planejamento $e$ Políticas Públicas, n. 21, jun, p. 211-259. Available at: https://www.ipea.gov.br/ppp/index.php/PPP/articl e/view/89. Accessed on: 28 mar. 2021.

Gelinski, C. R. O. G., \& Seibel, E. J. (2008). Formulação de políticas públicas: Relevant methodological issues. Revista de Ciencias Humanas, Florianópolis, EDUFSC, v. 42, n. I and 2, p. 227240, abr./out.

Getz, D. (1986). Models in Tourism Planning: towards integration of theory and practice. Tourism Management. 7(1), 21-32.

Gherghina, S., Ekaman, J., Podolian, O. (2019). Democratic innovations in Central and Eastern Europe: expanding the research agenda. 
Contemporary Politics, v. 25, n. 1, p. 1-10, 2019 https://doi.org/10.1080/13569775.2018.1543752.

Godoy, A. S. (1995). Pesquisa qualitativa: tipos fundamentais. Revista de Administração de Empresas. São Paulo, v. 35, n.3, mai/jun, p, 20-29.

Gomes, B. M. A. (2008). Políticas Públicas e as Transações em Regiões Turísticas. São Paulo: All Print Editora.

Gomes, B. M. A. (2018). Public policies of tourism and entrepreneurs. São Paulo: All Print Editora.

Gomes, B. M. A., Giannini, N., \& Bassani, C. P. (2020). Interacción Empresario-Sectorial en Turismo: un análisis institucional en Morretes, PR, Brasil. PASOS Revista De Turismo $Y$ Patrimonio Cultural, $\quad 18(3), \quad 431-441, \quad 2020$. https://doi.org/10.25145/j.pasos.2020.18.030

Gomes, B. M. A., \& Santos, A. C. (2007). Influências das políticas públicas de Turismo nas transações entre os agentes: uma análise sob a ótica da ECT. Revista Brasileira de Pesquisa em Turismo. v. 1, n. 2 , p. $72-100$, dec,

Grechi, D. C. (2011). O desenvolvimento turístico sob a ótica da economia institucional: uma análise do caso de Bonito/MS. Tese (doutorado). Programa de Pós-Graduação em Economia. Universidade Federal do Rio Grande do Sul.

Grechi, D. C., Lobo, H. A. S., Martins, P. C. S. (2019). As Estruturas de Governança e $\mathrm{O}$ desenvolvimento do Turismo. In. Machado, Katia de Assis Education and development: theoretical approaches and concrete experiences / Viviane Scalon Fachin, Fabrício Antonio Deffacci, Katia Resende de Assis Machado - Curitiba: CRV.

Hakak, A. M., Biloria, N., Dabbach, A., \& Venhari, A. A. (2016). "Thinking Out of the Box" from Out of the Box! Increasing the Dimension of "Starting Point" Case Study: Architecture Students. Psychology, v. 7 , $\mathrm{p}$, 345-355, 2016.http://dx.doi.org/10.4236/psych.2016.73037

Hall, S. (2014). A identidade cultural na pósmodernidade. Editora Lamparina.

Hjalager, A. M. (2010). A review of innovation research in tourism. Tourism Management, v. 31, n. 1, p. 112, feb. 2010 https://doi.org/10.1016/j.tourman.2009.08.012

Hodgson, G. M. (1992). Thorstein Veblen and postDarwinian economics. Cambridge Journal of Economics, v. 16, n. 3, p. 285-301, 1992. https://ideas.repec.org/a/oup/cambje/v16y1992i3p 285-301.html

Hodgson, G. M. (2000). What is the essence of institutional economics? Journal of Economic ISSues, v. 34 , n. 2, p. 317-329, jun. 2000. DOI: $10.1080 / 00213624.2000 .11506269$
Hodgson, G. M. (2004). What are Institutions? From Orders to Organizations. Rough Draft of 20 June 2004. The Business School, University of Hertfordshire, De Havilland Campus, Hatfild.

Hodgson, G. M. (2006). What are Institutions? Journal of Economic Issues, v. XL, n. 1, Mar., p. 1-25, 2006. https://doi.org/10.1080/00213624.2006.11506879

Ivars-Baidal, J., Celdrán, B. M. A, \& Feminia-Serra, F. (2017). Guía de implantación de Destinos Turísticos Inteligentes. Agència Valenciana del Turisme. Invat.tur, 2017. Available at: https://rua.ua.es/dspace/bitstream/10045/74386/4 /2017_Ivars-Baidal_etal_Guia-de-implantacionDTI-CV.pdf. Accessed on: 25 mar. 2021.

James, T., Jones, B. D., \& Baumgartner, F. R. (2007). Punctuated Equilibrium Theory: explaining stability and change in public policymaking. In: Paul A. Sabatier (org.), Theories of the Policy Process, Boulder, CO, Westview Press, pp. 155187.

Kingdon, J. W. (2011). Agendas, Alternatives and Public Policies, Boston, Longman (2nd revised edition).

Kofler, I., Marcher, A., Volgger, M., Peclaner, H. (2018). The special characteristics of tourism innovation network: the case of the Regional Innovation System in South Tyrol. Journal of Hospitality and Tourism Management, v. 37, p. 68-75, Dec. 2018. https://doi.org/10.1016/j.jhtm.2018.09.004

Lassasswell, H. D. (1956). The Decision Process. Seven Categories of Functional Analysis, College Park, MD, University of Maryland Press.

Leiper, N. (1979). The framework of tourism: towards a definition of tourism, tourist and the tourist industry. Annals of Tourism research, 6(4), 390407.

Mata, G. M. F., Pimentel, T., \& Emmendoerfer, M. L. (2019). Policy Arena, Policy Network and Social Field Theory in the study of Public Tourism Management. Caderno Virtual de Turismo, v. 19, n. 2 , 2019. http://www.ivt.coppe.ufrj.br/caderno/index.php/ca derno/article/view/1440/625

Meyer, J. W. (1977). The Effects of Education as an Institution. American Journal of Sociology, Chicago, v. 83, n. 1, p. 53-77.

Mitchell, W. C. (1914). Human behavior and economics: a survey of recent literature. The Quarterly Journal of Economies, v. 29, n. 1, p. 1-47, Nov. $1914 . \quad$ Available at: https://www.jstor.org/stable/pdf/1885296.pdf. Accessed on: 22 mar. 2021.

MTur. (1998). Planning Workshop of the PNMT/1998. Programa Nacional de Munipalização do turismo. Brasília, DF: MT. 
MTur. (2004). Programa de Regionalização do Turismo: roteiros do Brasil. Brasília, DF: MT.

MTur. (2006). Secretaria Nacional de Políticas de Turismo. Department of Planning and Evaluation of Tourism. Programa de Gestão Descentralizada do Plano Nacional de Turismo, 2003-2007. Fóruns e Conselhos Estaduais de Turismo. Brasília, DF: MTur.

MTur. (2020). BIMT 5th Edition: Market Trends in Tourism.

MTur. (2021). Inovation. MTUr announces cities that will integrate the pilot project Intelligent Tourism Destinations. Brasilília, DF: MTur, 2021. Available at: https://www.gov.br/turismo/ptbr/assuntos/noticias/mtur-anuncia-cidades-quevao-integrar-o-projeto-piloto-destinos-turisticosinteligentes

Muniz, E. C. L., Dandolini, G. A, \& Biz, A. A. (2021). A Customer Knowledge Management Framewrk. Journal of Information \& Knowledge Management, v. 20, n. 3., p. 1-33, September 2021.

https://doi.org/10.1142/S0219649221500283

Normalización Española - UNE. UNE 178502:2018. (2028). Indicadores y herramientas de los destinos turísticos inteligentes. 2018. Available at: https://Www.une.org/encuentra-tu-norma/buscatu-norma/norma/? $c=N 0060240$. Accessed on: 01 abr. 2021.

Normalización Española - UNE. UNE 178501:2018. (2018). Sistema de gestión de los destinos turísticos inteligentes. Requisitos. 2018. Available at: https://www.une.org/encuentra-tunorma/busca-tu-norma/norma?c=N0060239. Accessed on: 01 abr. 2021.

Normalización Española - UNE. UNE 178503:2019. (2021). Hotel Digital inteligente y conectado. Available at: https://Www.une.org/encuentra-tunorma/busca-tu-norma/norma?c=N0062377. Accessed on: 01 Apr. 2021.

Normalización Española - UNE. UNE 178503:2019. (2021). Intelligent tourist destinations. Semántica aplicada a turismo. Available at: https://Www.une.org/encuentra-tu-norma/buscatu-norma/norma?c=N0062377. Accessed on: 01 abr. 2021.

North, D. C. (1990). Institutions, Institutional Change and Economic Performance. Cambridge: Cambridge University Press.

Organisation fom Economic Co-Operation and Development - OECD - OECD. (2010). Tourism 2020: Policies to Promote Competitive and Sustainable Tourism, in OECD Tourism Trends and Policies 2010. OECD Publishing: Paris, 2010. Available at: https://doi.org/10.1787/tour-2010-4en. Accessed on: 19 Mar. 2021.
Organisation for Economic Co-Operation and Development - OECD/Eurostast. (1997). Oslo Manual: guidelines for collecting and interpreting data on innovation, 3rd ed.

Organisation for Economic Co-Operation and Development - OECD/Eurostast. (2018). Oslo Manual 2018: Guidelines for collecting, reporting and using data on innovation, $4^{\text {th }}$ ed. Luxembourg: OECD Publisching, 2018. Available at: https://www.oecd.org/science/oslo-manual-20189789264304604-en.htm. Accessed on: 02 Apr. 2021.

Panosso Netto, A., \& Castillo Nechar, M. (2014). Epistemology of tourism: theoretical schools and critical proposal. Revista Brasileira de Pesquisa em Turismo. São Paulo, v.8, n. 1, p.120-144, jan./mar.

Pearce, D. (1987). Tourism Today: a geographical analysis. England, 1987.

Portugal, Turismo de Portugal. (2017). Tourism 4.0 program. 2017. Available at: http://business.turismodeportugal.pt/pt/Conhecer Inovacao/turismo-4-0/Documents/Turismo40apresentacao-LA-2017.pdf. Accessed on: 28 mar. 2021.

Portugal, Turismo de Portugal. (2017). Tourism 4.0. 2017. Available at: http://business.turismodeportugal.pt/pt/Conhecer /Inovacao/turismo-4-0/Paginas/default.aspx. Accessed on: 28 mar. 2021.

Portugal Turismo de Portugal. (2017). Tourism Strategy 2027. 2017. Available at: http://Www.turismodeportugal.pt/pt/Turismo_Por tugal/Estrategia/Estrategia_2027/Paginas/defaul t.aspx. Accessed on: 28 Mar. 2021.

Portugal Presidency of the Council of Ministers. (2017). Resolution of the Council of Ministers No. 134/2017. Diário da República, 1. ${ }^{\mathrm{a}}$ série - N. ${ }^{\mathrm{o}} 187$ 27 September 2017, p. 5522 - 5532. Available at: https://dre.pt/web/guest/home/-

/dre/108219721/details/maximized?serie=I\&dreId =108219717. Accessed on: 28 mar. 2021.

Ratten, V., \& Braga, V. (2019). Tourism innovation. Journal of Hospitality and Tourism Management, v. $41, \quad$ p. $171-174, \quad$ Dec. 2019. https://doi.org/10.1016/j.jhtm.2019.10.002

Rodríguez, I., Willians, A. M., Hall, M. (2014). Tourism innovation policy: Implementation and outcomes. Annals of Tourism Research, v. 49, p. 76-93, Nov. 2014. http://dx.doi.org/10.1016/j.annals.2014.08.004

Rua, M. G. (1998). Análise de Políticas Públicas: Conceptos Básicos. In: Rua, M. das G., Valadão, M. I. O Estudo da Política: Temas Selecionados. Brasília: Paralelo 15. 
Sabatier, P. A. (2007). (org.). Theories of the Policy Process, Boulder, CO, Westview Press.

Shumpeter, J. A. (1934). The theory of economic development. Cambridge. MA: Harvard University Press.

Simon, H. A. (1955). A Behavioral Model of Rational Choice. Quartely Journal of Economics, v. 69, n. 1, feb., p. 99-118.

Smith, G. (2009). Democratic Innovations: designing institutions for citizen participation. Cambridge University Press: New York.

SEGITTUR. (2017). Intelligent Tourism Destinations. $2017 . \quad$ Available at https://Www.segittur.es/destinos-turisticosinteligentes/proyectos-destinos/destinosturisticos-inteligentes/. Accessed on: 02 Apr. 2021.

SEGITTUR. (2021). Member of the Network. 2021. Available https://www.destinosinteligentes.es/miembros- $\mathrm{y}^{-}$ funcionamiento-red-dti/. Access on: 20 mai. 2021.

Sotang, D., Gomes, B. A, \& Vargas, A. (2020). Users agenda in tourism public policies: an analysis in Curitiba (Brazil). Turismo y Sociedad, xxvii, p. 95109 2020 .

Doi https://doi.org/10.18601/01207555.n27.05

Souza, C. (2006). Políticas Públicas: uma revisão de literatura. Sociologias, Porto Alegre, ano 8, n. 16, jul/dez, p. 20-45, 2006.

Souza, C. (2007). Estado da arte da pesquisa em políticas públicas. In: Hochman, G, Arretche, M., Marques, E. Políticas públicas no Brasil. Rio de Janeiro: Editora Fiocruz.

Spain, Ministerio de Energía, Turismo Y Agenda Digital. (2017). Plan Nacional de Territorios Inteligentes. Diciembre 2017. Madrid, 2017. Available at: https://avancedigital.mineco.gob.es/es ${ }^{-}$ es/Novedades/Documents/Plan_Nacional_Territo rios_Inteligentes.pdf. Accessed on: 02 Apr. 2021.

Spain, Ministerio de Industria, Energía Y Turismo. (2015). Plan Nacional e Integral de Turismo 2012 2015. Madrid, 2012. Available at: https://turismo.gob.es/eses/servicios/Documents/Plan-Nacional-IntegralTurismo-2012-2015.pdf. Accessed on: 01 Apr. 2021.

Spain, Ministerio de Industria, Turismo Y Comercio. (2020). Por y para todos... Turismo 2020 Plan del Turismo Español Horizonte 2020. 2007. Available at: content/themes/wp-bootstrap 4/assets/planes/2007_Plan_Horizonte_Turismo_2 020.pdf. Accessed on, 27 Mar. 2021.

Spain, Ministerio de Industria, Turismo Y Comercio. (2020). Turismo 2020 Plan del Turismo Español
Horizonte 2020. Available at: https: $: / W W w$. tourspain.es/eses/Conozcanos/Documents/HistoricoPoliticaTuris tica/PlanTurismoEspanolHorizonte2020.pdf. Accessed on: 27 Mar. 2021.

Spain. (2007). Presidencia del Gobierno. Consejo de Ministros. The Government approves the Spanish Tourism Plan Horizonte 2020 and promotes the access of disabled people to the Information Society. La Moncloa, Madrid, Thursday, 8 November 2007. Available at: https://www.lamoncloa.gob.es/consejodeministros /resumenes/Paginas/2007/081107-Consejo.aspx. Accessed on: 27 Mar. 2021

Portugal, Turismo de Portugal. (2017). Tourism 4.0. Lisbon, 2017. Available at: http://business.turismodeportugal.pt/pt/Conhecer /Inovacao/turismo-4-0/Paginas/default.aspx. Accessed on: 15 mar. 2021.

Tude, J. M. (2010). Conceitos gerais de políticas públicas. In: TUDE, João Martins, FERRO, Daniel and SANTANA, Fabio Pablo (Orgs.). Public Policy, IESDE Brasil S. A.

Veblen, T. (1919). The Place of Science in Modern Civilization and Other Essays. New York: Huebsch, 1919. Available at: https://archive.org/details/01610020R.nlm.nih.go v/page/n1/mode/2up. Accessed on: 22 mar. 2021

Vilela, G. J. P., \& Costa, H. A. (2018). Public Policies in Tourism from the perspective of Complexity: reflections on interactions between public and private aspects. Cenário: Revista Interdisciplinar em Turismo e Território Brasília, v. 5, n. 9, p. 8395, 2018. doi:10.26512/revistacenario.v5i9.19435.

Weidenfeld, A. (2013). Tourism and Cross Border Regional Innovation Systems. Annals of Tourism Research, v. 42, p. 191-213, 2013. http://dx.doi.org/10.1016/j.annals.2013.01.003

Williamson, O. (1985). Transaction cost economics. In: WILLIAMSON, O. The economic institution of capitalism. London: The Free Press, p. 15-42.

Williamson, O. (1996). Comparative Economic Organization: The Analysis of Discrete Structural Alternatives. In: Mechanisms of Governance. Oxford: Oxford University Press.

WEF. (2019). The Travel \& Tourism Competitiveness Report 2019. Available at: https://Www.weforum.org/reports/the-traveltourism-competitiveness-report-2019. Accessed on: 01 Apr. 2021.

UNWTO. (2020). International Tourism Highlights, 2020 Edition. UNWTO: Madrid. 2021. Available at: DOI: https://doi.org/10.18111/9789284422456. Accessed on: 01 Apr. 2021. 
WTTC. (2017). Understanding the critical issues for the future of Travel \& Tourism. March.

Zach, F. J, HILL, T.L. (2017). Network, knowledge and relationship on innovation in tourism destinations. Tourism Management, v. 62, p. 196207, 2017. http://dx.doi.org/10.1016/j.tourman.2017.04.001 


\section{INFO PAGE \\ PUBLIC POLICIES, TOURISM AND INNOVATION: AN ANALYSIS OF THE CASES TURISMO 4.0 (PORTUGAL) AND SMART TOURISM DESTINATION (SPAIN)}

\section{Abstract}

The paper on public policies, tourism and innovation gave the opportunity to reflect on traditional concepts of public policies, based on the current scenario permeated by changes caused by innovations in different areas. The effort to relate the different theoretical approaches was based on the analysis of two exemplary cases: Portugal and Spain. Both countries have produced innovative public policies regarding tourism management, be they procedural, organizational, marketing, institutional or reverse innovations. The methodology had a qualitative approach, comprising theoretical review and case study. The analysis of the documents was based on the reference on public policy analysis, with attention to the models of institutional and systemic orientation and the cycle of public policies on the possibilities of innovation for tourism, and the vision of democratic innovation. Knowing the historical process and the institutional context inherent to the cases studied allowed a critical look at the Brazilian panorama, considering the challenges and possibilities of the policies for the sector, based on innovation and all stages of the policy cycle.

Keywords: innovation, public policies, tourism, institutionalism

\section{Authors}

\begin{tabular}{clc}
\hline Full Name & \multicolumn{1}{c}{ Author contribution roles } & Contribution rate \\
\hline Alexandre Augusto Biz: Conceptualization, Methodology, Formal analysis, Investigation, Resources, Writing - Original Draft, Writing - Review \& \\
Editing,
\end{tabular}

Author statement: Author(s) declare(s) that All procedures performed in studies involving human participants were in accordance with the ethical standards of the institutional and/or national research committee and with the 1964 Helsinki declaration and its later amendments or comparable ethical standards. Declaration of Conflicting Interests: The author(s) declared no potential conflicts of interest with respect to the research, authorship, and/or publication of this article

This paper does not required ethics committee report Justification: The methodology of this study does not require an ethics committee report. 